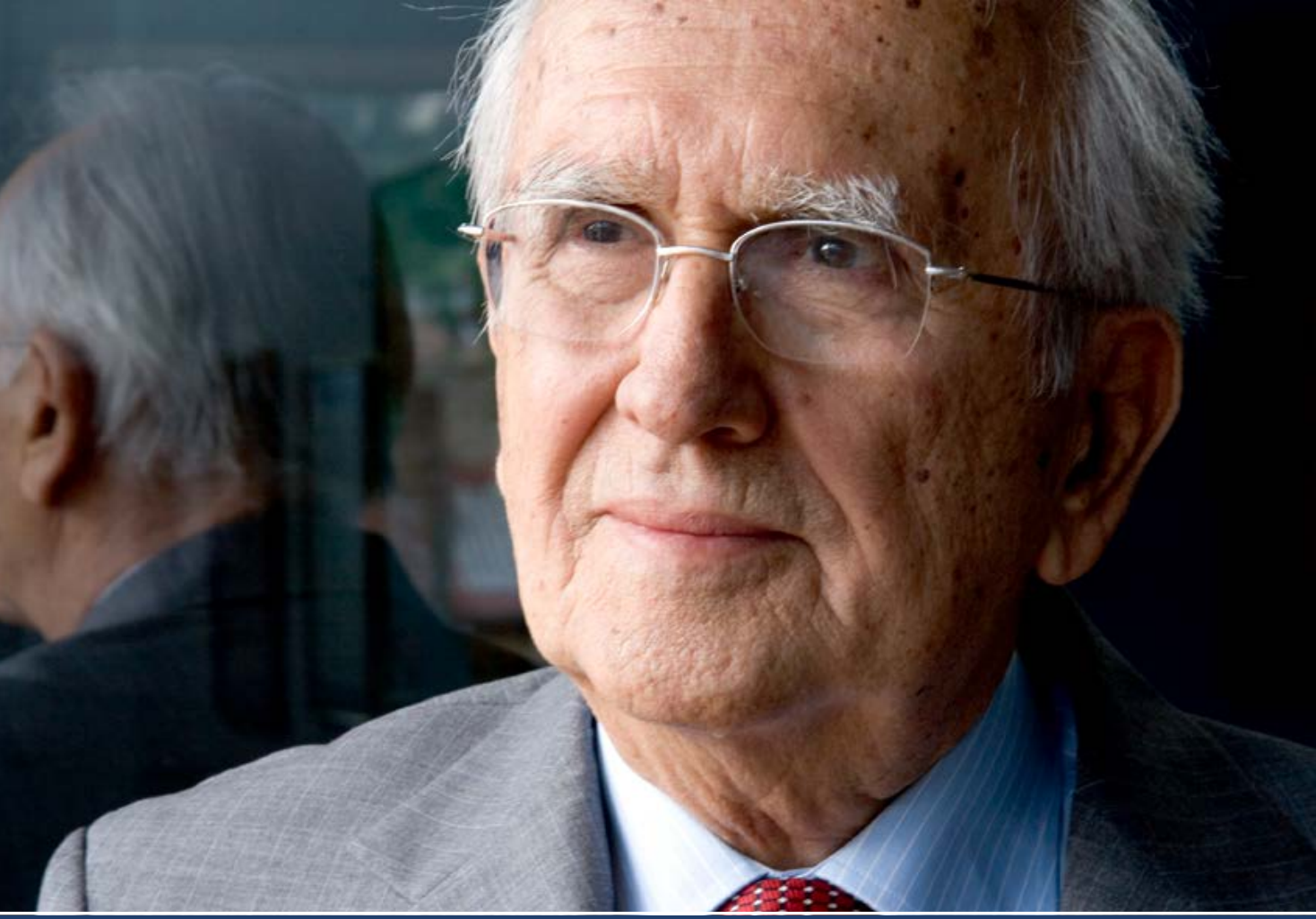

\title{
Političko i kulturno naslijeđe Adila Zulfikarpašića (skica za studiju)
}

Doc. dr. Amir Duranović

27-40.

Adil Zulfikarpašić i liberalne političke inicijative ZBORNIK RADOVA 


\title{
Političko i kulturno naslijeđe Adila Zulfikarpašića (skica za studiju)
}

\author{
Doc. dr. Amir Duranović \\ Filozofski fakultet Univerziteta u Sarajevu \\ amir.duranovic@ff.unsa.ba
}

Sažetak: Autor u ovome radu daje skicu za studiju o političkom i kulturnom naslijeđu Adila Zulfikarpašića, njegovom porijeklu, odnosu prema politici, emigraciji, političkom angažmanu i najznačajnijoj zadužbini savremene bošnjačke kulturne scene - Bošnjačkom institutu - Fondaciji
Adila Zulfikarpašića, koja je osnovana u Švicarskoj, a sada djeluje u Bosni i Hercegovini.

Ključne riječi: Adil Zulfikarpašić, Bosna i Hercegovina, Bošnjaci, Bošnjački institut.

Uvodeći čitaoce u tekst knjige o Adilu Zulfikarpašiću Bošnjačka ideja autora Šaćira Filandre i Enesa Karića, Mustafa Imamović, jedan od najznačajnijih bošnjačkih i bosanskohercegovačkih naučnika druge polovine XX stoljeća, zabilježio je kako „bošnjačka literatura, u najširem smislu riječi, još ne zna za neku pravu povijesnu i književnu biografiju, pa ni biografiju-roman ili romansiranu biografiju”. ${ }^{1}$ Ovakva tvrdnja, izrečena na početku novog milenija, 2002. godine, danas se više ne bi mogla iskazati s toliko samouvjerenosti, kako je to Imamović učinio prije skoro dvije decenije. Situacija se, srećom za bosanskohercegovačku historiografiju i publicistiku, znatno promijenila budući da se u proteklom periodu napisalo i objavilo nekoliko historiografski veoma utemeljenih, a dobro prihvaćenih, prije svega političkih biografija najistaknutijih ličnosti savremene bosanskohercegovačke historije, $s$ tim što ozbiljno treba računati i na mogućnost da se takva djela ne percipiraju samo i isključivo kao „bošnjačka literatura”. Naravno, ni nešto starije epizode bosanske historije nisu ostale zakinute u tom pogledu, ${ }^{2}$ ali to pitanje trenutno nije relevantno za teze

\footnotetext{
Šaćir Filandra i Enes Karić, Bošnjačka ideja. Zagreb: Nakladni zavod Globus, 2002, 7.

2

Vidjeti, npr., Behija Zlatar, Gazi Husrev-beg. Sarajevo: Orijentalni institut, 2010.
} 
o kojima ovdje govorim. Za razliku od vremena kada je Imamović iznio ovu tvrdnju, bosanskohercegovačka akademska, ali i šira javnost danas je u prilici čitati historiografski utemeljene i ozbiljne političke biografije iz pera pripadnika srednje i mlađe generacije bosanskohercegovačih historičara. Husnija Kamberović i Admir Mulaosmanović, naprimjer, autori su dobro prihvaćenih i pozitivno ocijenjenih biografija o Mehmedu Spahi ${ }^{3}$ i Džemalu Bijediću (Kamberović) ${ }^{4}$ te Aliji Izetbegoviću (Mulaosmanović), ${ }^{5}$ a cjelokupnoj priči na tom mjestu nije kraj jer se i o drugim akterima savremene bosanskohercegovačke historije pišu i objavljuju političke biografije. ${ }^{6}$ Dakako, ovdje navedene naslove treba čitati i razumijevati kako u kontekstu vremena u kojem su nastali tako i u razvojnoj liniji bosanskohercegovačke historiografije, čija će cjelovitija ocjena moći biti sačinjena onda kada bude napisana historija bh. historiografije. Ni autori publicističkih i romansiranih biografija nisu ostali na pozicijama kakve su bile početkom 200o-ih, pa se javnost ipak može referirati kako na publicističke tako i na romansirane biografije pojedinih ličnosti iz bosanskohercegovačke i bošnjačke historije. Sve to je, zapravo, pokazatelj kako se interes akademske, pa i šire javnosti za značajnim ličnostima postepeno povećava i raste, što bi se moglo tumačiti barem dvojako. S jedne strane, mogli bismo tvrditi kako savremeni društveno-politički kontekst u Bosni i Hercegovini kao da traži isticanje „velikih muževa” i njihove uloge u određenoj fazi historije te zemlje, moguće u nedostatku takvih među savremenim političkim akterima, ako su takvi uopće potrebni - što je teza na koju s razlogom treba skrenuti pažnju - dok, s druge strane, to može biti pokazatelj kako se savremena bosanskohercegovačka historiografija, prije svih drugih disciplina, još drži tradicionalnih metodoloških pristupa prilikom odabira i elaboracije istraživačkih tema, iako su u tom segmentu nama susjedne

3 Husnija, Kamberović, Mehmed Spaho (7883-1939): politička biografija. Sarajevo: Vijeće Kongresa bošnjačkih intelektualaca, 2009.

4

Husnija, Kamberović, Džemal Bijedić: politička biografija. Mostar: Muzej Hercegovine, 2012. Drugo, dopunjeno izdanje knjige: Husnija, Kamberović, Džemal Bijedić: politička biografija, 2. dopunjeno izdanje. Sarajevo: Udruženje za modernu historiju / Udruga za modernu povijest Sarajevo, Edicija: Studije za historiju BiH, knj. 3, 2017.

5

Admir Mulaosmanović, Iskušenje opstanka: Izetbegovićevih deset godina 1990.-2000. Sarajevo: Dobra knjiga, 2013. Drugo, autorsko izdanje: Admir Mulaosmanović, Iskušenje opstanka. Izetbegovićevih deset godina 1990.-2000. 2. izdanje. Sarajevo, 2017. Pogled na historiografske ocjene ovdje navedenih biografija i njihov značaj za savremenu bosanskohercegovačku historiografiju vidi u: Amir Duranović, „Debate About Personality as a Factor in Modern Bosnian History: An Assesment of Historiography of Bosnia and Herzegovina", Historia Moderna - Bosnia \& Herzegovina, God. I, br. 1, 2020, 43-56.

6

Dženita Sarač-Rujanac, Branko Mikulić: politička biografija: 1965-1989. Sarajevo: Institut za historiju Univerziteta u Sarajevu, 2020. 
historiografije, da ne ističem primjere iz drugih, znatno otišle naprijed u širenju spektra istraživačkih mogućnosti, što se može vidjeti i na nekim drugim vrijednim primjerima iz bosanskohercegovačke historiografije, a koji nisu tematski vezani za ovdje skiciranu temu.

U tom svojevrsnom prostoru nadmetanja jedne i druge navedene pozicije situira se potreba novog istraživačkog poduhvata i potencijalno svježijeg pogleda na „život i djelo” Adila Zulfikarpašića, istaknute bosanskohercegovačke javne ličnosti, političara, emigranta, biznismena, kulturnog mecene, vakifa i dobrotvora.? Iako bi se niz pojmova vezanih za njegovu ličnost mogao nastaviti i dalje, što također može biti istraživački interesantno i dokumentaristički vrijedno, jer bi se time pokazalo šta je sve Adil Zulfikarpašić bio, ali i kako je bio doživljavan, čak i kako se doživljava danas kada više nije među živima, cilj je ovoga rada prezentirati ključne teze za razumijevanje političkog i kulturnog naslijeđa Adila Zulfikarpašića, ličnosti s kojom se mora računati želi li se temeljitije razumjeti savremena bosanskohercegovačka historija te mjesto i uloga Bošnjaka u njoj.

Razumijevanje političkog i kulturnog naslijeđa Adila Zulfikarpašića potrebno je prezentirati na način da se između dvije „međusobno povezane literarne forme", historiografske i naučno-popularne, pronađe svojevrsna ravnoteža, gdje Zulfikarpašić, kojem je studija posvećena, neće biti izdvojen izvan konteksta u kojem je djelovao u različitim epizodama svoga života niti bi kontekst u kojem kao ličnost djeluje trebao dominirati iznad ličnosti. Iako se o njegovom porijeklu mnogo pisalo i govorilo, naročito $\mathrm{u}$ intervjuima koje je davao nakon povratka iz emigracije, ${ }^{8}$ porijeklo Adila Zulfikarpašića, odnosno njegove porodice, i dalje je vrijedno istraživačke pažnje, kako se može vidjeti iz historiografske literature, ali i ne samo nje.

7

Broj radova koji neposredno i posredno govore o Adilu Zulfikarpašiću prelazi stotine bibliografskih jedinica različite namjene, formata i kvaliteta, ali za uvid o dosadašnjim pokušajima pojašnjenja mjesta i uloge Adila Zulfikarpašića u savremenoj bosanskohercegovačkoj historiji vidi: Šaćir Filandra i Enes Karić, Bošnjačka ideja. Zagreb: Nakladni zavod Globus, 2002; Šaćir Filandra, Bošnjačka politika u XX. stoljeću. Sarajevo: Sejtarija, 1998; Mustafa Imamović, Bošnjaci u emigraciji: monografija „Bosanskih pogleda”. Zürich (odjel Sarajevo): Bošnjački institut, 1996; Milovan Đilas i Nadežda Gaće, Bošnjak Adil Zulfikarpašić. Zürich: Bošnjački institut, 1994; Adil Zulfikarpašić, Članci i intervjui (prir. Nadežda Gaće). Zürich (i odjel Bošnjačkog instituta u Sarajevu): Bošnjački institut, 1991; Fahrudin Đapo i Tihomir Loza, Povratak u Bosnu (razgovori s Adilom Zulfikarpašićem). Ljubljana: Karantanija, 1990. Također, za poglede na historiju, ali politički angažman te ključne političke stvove koje je zagovarao 1990 -ih godina, vidjeti: „Bošnjak se vratio iz emigracije”, Valter Express, br. 23, 1990, 9-14; „Sposobni smo da budemo dio Evrope”, vOX, br. 7, 1990, 27-34; Лука Мичета, „Судбина Бошњака. Сведочење Адила Зулфикарпашића”, НИН (специјални додатак), 27. јул 1997, 3-50. 8

Vidjeti, na primjer, dio razgovora o porijeklu u: Лука Мичета, „Судбина Бошњака. Сведочење Адила зулфикарпашића", НИН (специјални додатак), 27. јул 1997, 3-50. Također, vidjeti i Milovan Đilas i Nadežda Gaće, Bošnjak Adil Zulfikarpašić. Zürich: Bošnjački institut, 1994. 
Naime, porijeklo iz „stare i razgranate begovske familije” Čengića ${ }^{9}$ ima jednu specifičnost u odnosu na druge begovske porodice u Bosni i Hercegovini, ili njihov najznačajniji dio. Riječ je o porodici koja nije domaćeg etničkog porijekla, ali koja je, zahvaljujući okolnostima i društveno-ekonomskom kontekstu u kojem se vezala za Bosnu, dijelom opredijelila svoju budućnost vezanjem za Bosnu i Hercegovinu i njenu historiju - što se na primjeru odnosa Adila Zulfikarpašića prema tom pitanju možda i ponajbolje vidi. Zulfikarpašići, kao ogranak porodice Čengića koji su u Bosnu došli sredinom 16. stoljeća iz Anadolije ${ }^{10}$ i nastanili se isprva na Zagorju, visoravni koja se prostire ,između planina Treskavica i Zelengora”, a za koju je Johann Asboth zapisao da je „stjenovita visoravan sa oskudnom vegetacijom u središtu surovih snjegovitih planina [...]", ${ }^{11}$ i selu Borije, gdje je bio njihov prvi odžak, u narednom su se periodu razgranali po okolnim selima na Zagorju (uz Borije, u 19. stoljeću Čengića je bilo i u naseljima Jelašca, Kuta, Mjehovine, Hotovlje, Zelumići i Vihovići), a potom šire u Podrinju (Rataji, Miljevina, Srbotina, Odžak kod Ustikoline, Foča, Potpeć, Lokve i Višegrad), Pljevljima, pojedinim krajevima oko Sarajeva, a „u 19. stoljeću posebno su se isticali pripadnici ove porodice nastanjeni u Gacku”. ${ }^{12}$

Dugogodišnje iskustvo susreta, nadmetanja i sukoba na granici sa Crnom Gorom od pripadnika te porodice načinilo je u tradiciji, ali i historiografiji, prepoznate i istaknute ličnosti. Promjenom paradigme, odlaskom osmanske vlasti i dolaskom austrougarske administracije, dijelom se mijenjao odnos prema vlasti, ali kako to bilježe istraživanja o begovskim porodicama i njihovim zemljišnim posjedima, članovi porodice se, naročito nakon ustanka u Hercegovini 1882. godine, uglavnom „,integriraju u novu društvenu stvarnost i zauzimaju značajne upravne položaje", ${ }^{13}$ što se može vidjeti i iz činjenice da su pojedini članovi porodice „dobili odlikovanja viteškog reda" od cara Franza Josefa, a prema bilješkama ranije spomenutog

9

Hamdija Kreševljaković, Čengići: prilog proučavanju feudalizma u Bosni i Hercegovini. Sarajevo, 1959. Sažeto i istraživački veoma utemeljeno o Čengićima kao veleposjedničkoj begovskoj porodici vidi u: Husnija Kamberović, Begovski zemljišni posjedi u Bosni i Hercegovini od 1878. do 1918. godine. Sarajevo: Naučnoistraživački institut „IBN SINA”, drugo izdanje, 2005, 288-294.

10

Kosta Hörmann, Narodne pjesme Bošnjaka u Bosni i Hercegovini, 6o6-610.

11

Johann Asboth, Bosnien und die Herzegowina. Reisebilder und Studien. Wien: 1888. (dio prijevoda pod naslovom „Foča i Zagorje" objavljen u časopisu Život, br. 1, 1979, 74-93)

12

Husnija Kamberović, Begovski zemljišni posjedi, 289.

13

Isto. 
J. Asbotha, „neke su nazivali i grofovima”. ${ }^{14} \mathrm{U}$ generalnoj ocjeni austrougarskog perioda posebno se ističe i „zapažena (je) uloga Husein bega Čengića Zulfikarpašića, dugogodišnjeg fočanskog načelnika”, ${ }^{15}$ Adil-begovog oca i čovjeka koji je, prema Adil-begovom svjedočenju, najviše utjecao na njega i prema kome je gajio naročito poštovanje, odnosno čovjeka koji mu je bio „jedina fascinacija u životu”. ${ }^{16}$

Ipak, onaj dio porodice koji se nije uspio uklopiti u novi društveno-politički poredak iselio se u druge dijelove Osmanskog carstva u talasima iseljavanja, čije brojke dosežu nekoliko stotina hiljada. ${ }^{17}$ Među takvima su bile i mnoge poznate ličnosti porodice Čengić, „naročito Osman Mahzar paša, Derviš pašin sin, a zatim Hajdar-beg, koji je u januaru 1882. iselio iz Rožanovića (kotar Foča) u Istanbul, a kasnije se preselio u Bursu, zatim Smail Junusbeg, unuk mnogo poznatijeg Smail-age Čengića” ${ }_{18}$ i brojni drugi. Prema istraživanjima Husnije Kamberovića, Čengići su se na prijelazu iz 19. u 20. stoljeće približili „samom vrhu bosanske begovske zemljoposjedničke elite”, među kojima posebno ističe ogranak nasljednika Smail-age Čengića „te ogranak porodice koji se naziva Zulfikarpašić. ${ }^{19}$ Veliki zemljišni posjedi rasprostranjeni na teritoriji Prnjavora i Foče, a zatim Gacka, Nevesinja, Bileće, Višegrada i Rogatice, posljedica su značaja koji je porodica imala u osmanskom periodu bosanske historije, ali i činjenice da su se posjedi kako u tom tako i u austrougarskom periodu uvećavali naročito udadbeno-ženidbenim vezama sa drugim begovskim porodicama, među kojima Kamberović posebno ističe Sulejmanpašiće. ${ }^{20}$ Među brojnim beglučkim zemljištem „najveći su bili posjedi Husein-bega Čengića Zulfikarpašića, koji

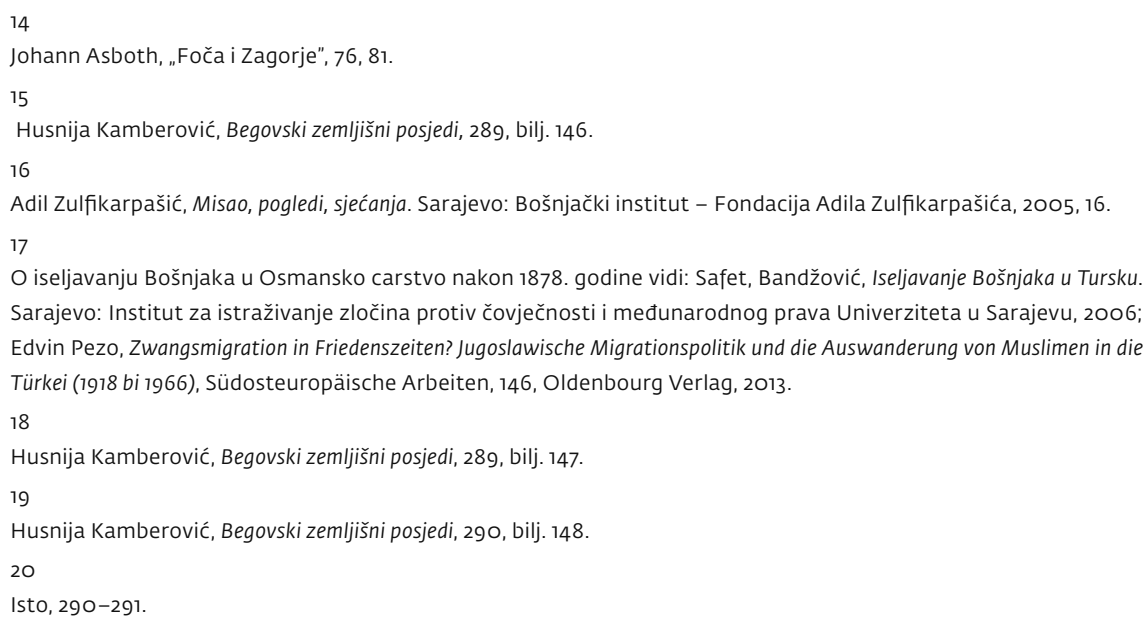
Sarajevo: Institut za istraživanje zločina protiv čovječnosti i međunarodnog prava Univerziteta u Sarajevu, 2006; Edvin Pezo, Zwangsmigration in Friedenszeiten? Jugoslawische Migrationspolitik und die Auswanderung von Muslimen in die Türkei (1918 bi 1966), Südosteuropäische Arbeiten, 146, Oldenbourg Verlag, 2013. 
su u Jabuci, Jeleču i Ljubini obuhvatali površinu od 5.655,1 dunum”, ${ }^{11}$ iako u ukupnim brojkama posjeda nisu zaostajali ni nasljednici Smail-age Čengića.

Premda je do potpunih podataka teško doći, naročito za period poslije 1918. godine, kada je „reformom” regenta Aleksandra Karađorđevića „riješeno agrarno pitanje”, 22 činjenica da se u austrougarskom periodu pojavljuje mali broj drugih begovskih zemljoposjedničkih porodica na području istočne Bosne pokazuje kako je porodica Čengića, zapravo, bila u samome vrhu zemljoposjedničke elite u Bosni i Hercegovini, naročito u istočnoj Bosni. ${ }^{23}$

No, kako je 1918. godine u historiji Bosne i Hercegovine, pa i Bošnjaka, nastala nova i „krupna promjena”, kako se o tome izrazio Skender Kulenović u svome Pogledu na muslimansku omladinu 1937. godine, slijed događaja doveo je većinu mladih ljudi pred izbor „umrijeti ili živjeti”. Kulenović navodi da su neki krenuli „u škole, i tu većinom [omladina] zastade što iz nemogućnosti školovanja, što iz nerazvijene svijesti o potrebi škole, neka se prihvati zanata, a najveći dio pođe putem lumpenproletera”. Izvan ove većine o kojoj govori Kulenović, ostao je izuzetak koji čine „krupniji begovi, koji su, primivši neke tekovine zapadnoevropske civilizacije, razvili kod sebe neki smisao za školu i koji su, pretvorivši agrarnom reformom neobuhvaćenu imovinu u kapitalističku, imali mogućnost da svoju djecu školuju”. ${ }^{4}$ Upravo u vrijeme o kojem ovdje tako sažeto, a istovremeno veoma precizno govori Skender Kulenović odrastao je Adil Zulfikarpašić, iz čijih se sjećanja na djetinjstvo i društvenu poziciju njegovog oca Husein-bega Zulfikarpašića iščitavaju upravo ove konture opredijeljenosti i preuzimanja pojedinih tekovina zapadnoevropske civilizacije i razumijevanje značaja obrazovanja. ${ }^{25}$

Politički put Adila Zulfikarpašića, od SKOJ-evskih, revolucionarno-ratnih i poslijeratno-emigrantskih dana do pune političke afirmacije nakon povrataka iz emigracije tokom 1990-ih godina 20. stoljeća, iako je u suštinskom smislu politički stasavao u emigraciji i učinio prijelomne korake u afirma-

21

Isto, 291.

22

O agrarnoj reformi i njenom zakonodavstvu vidi: Edin Mutapčić, Agrarna reforma u BiH i njeno zakonodavstvo (1918.1941.). Gradačac: Javna biblioteka „Alija Isaković”, 2007.

23

Husnija Kamberović, Begovski zemljišni posjedi, 294

24

Nav. prema: Husnija Kamberović, Begovski zemljišni posjedi, 10

25

Šaćir Filandra i Enes Karić, Bošnjačka ideja, 324 
ciji i igradnji identiteta bošnjačke emigracije, ${ }^{26}$ samo je jedna i veoma često eksploatirana dimenzija njegove i dalje intrigantne ličnosti. Jedna sasvim druga dimenzija, koju u najširem smislu treba razumijevati u kontekstu kulturnog naslijeđa koje je Adil Zulfikarpašić ostavio iza sebe, zavređuje posebnu pažnju. Husein-beg Zulfikarpašić, dugododišnji gradonačelnik Foče, istaknuti bosanski beg i učesnik značajnijih događaja iz bosanskohercegovačke i bošnjačke historije na početku 2o. stoljeća, posebno je utjecao na Adil-begovo formiranje pogleda na život i svijet, odnos prema nauci, obrazovanju, politici i društvenom životu i odgovornosti, ${ }^{27}$ svim onim aspektima koji su u kasnijoj fazi Adil-begovog života bili naročito zapaženi. Za razumijevanje ideje kulturnog naslijeđa Adila Zulfikarpašića pojam i ideja obrazovanja čine posebnu cjelinu. ${ }^{28}$

Kako se okončanjem Prvog svjetskog rata na prostoru Jugoistočne Evrope završila jedna velika epoha ne samo regionalne nego i svjetske povijesti krah velikih imperija koje su dominantno odredile društveno-političku, religijsku i kulturološku sliku regiona - promjene od 1918. godine nadalje bile su rezultat upravo tog velikog, završnog loma, poslije kojeg su velike svjetske imperije, kakvo je bilo Osmansko carstvo ili Austro-Ugarska monarhija, suštinski i formalno prestale postojati, ${ }^{29}$ a nove (nacionalne) države nasljednice su izgradnju vlastitog legitimiteta u velikoj mjeri temeljile na delegitimiranju prethodnih sistema vlasti, što se, u veoma konkretnim potezima vlasti novoformiranog Kraljevstva Srba, Hrvata i Slovenaca, odrazilo i na zemljoposjednički sloj Bošnjaka u Bosni i Hercegovini. Stoga je neizbježno u ovom dijelu skretanje pažnje i na pitanje poznato u literaturi kao agrarna reforma, kao i poziciju bosanskohercegovačke zemljoposjedničke elite, konkretno Čengića i Zulfikarpašića, prema navedenom pitanju. U više je navrata svojim pismima jugoslavenskim vlastima Husein-beg Zulfikarpašić događaje iz 1918. godine okarakterisao pojmom „prevrat”, termin uz koji je i Adil odrastao. Takvom se leksikom pokazuje ne samo stav prema tadašnjim jugoslavenskim vlastima nego i dio motiva koji su uglavnom mlade i razočarane nasljednike unutar begovskih porodica orijentirale prema političkoj opciji i programima čiji je cilj bio „pravednije i drugačije” organiziranje društveno-političkih odnosa. Otuda se među

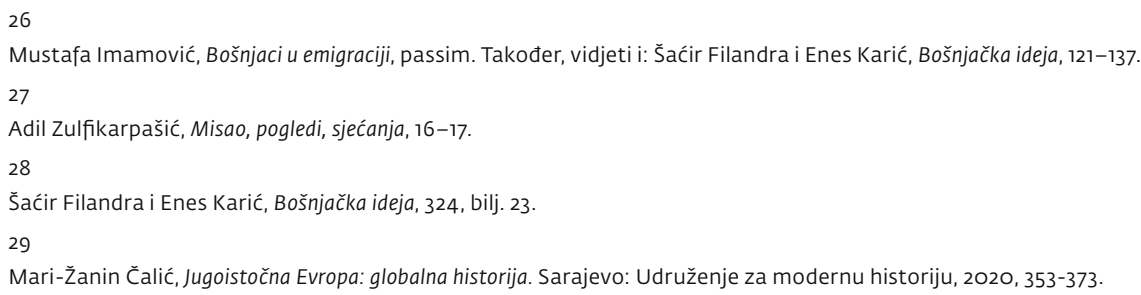


članovima tada ilegalne Komunističke partije našao i znatan broj potomaka begovskih porodica, a što se može iščitati i iz „,kkojevskih opredjeljenja” mladog „ljevičara” Zulfikarpašića. ${ }^{30}$ Kako su svjetska gibanja u prvoj polovini 20. stoljeća bila mnogo dinamičnija u odnosu na prethodne epohe, to su i smjene državno-pravnih okvira bile mnogo češća pojava u 20. stoljeću bosanskohercegovačke historije nego ikada ranije. U toj novoj dinamici svjetske povijesti monarhistička Jugoslavija nestala je nakon nešto više od dvije decenije postojanja, ${ }^{31}$ a Drugi svjetski rat je, osim mogućnosti za značajnije promjene brojnih društveno-političkih unutrašnjih pitanja, uz najznačajnije pitanje opstanka, omogućio i ,izlazak iz ilegale” pripadnicima jugoslavenskog komunističkog pokreta koji su, dobivši mogućnost da aktivno djeluju na sceni, krenuli u izgradnju svijeta „po svojoj mjeri”. Okolnosti i dešavanja u prvim godinama rata mladom su Zulfikarpašiću donijeli i borbu za opstanak, robiju, ${ }^{32}$ ali i prva razočarenja u pokret, ${ }^{33}$ ideologiju, konkretne ljude i njihove poteze. ${ }^{34} \mathrm{~S}$ vremenom je takav odnos rezultirao otvaranjem sasvim nove stranice u životu sada već odraslog, ali i dalje mladog Zulfikarpašića - odlazak u emigraciju. ${ }^{35}$ Njegovi pogledi na Drugi svjetski rat, ${ }^{36}$ zločine nad Bošnjacima u istočnoj Bosni, ${ }^{37}$ odnose među nosiocima komunističke vlasti koja je nastajala u uvjetima Drugog svjetskog rata, a naročito u njegovoj samoj završnici, te pogledi na kontekst i okolnosti uspostavljanja nove vlasti tokom 1945. godine treba čitati i razumijevati i kontekstu kritičkog sagledavanja perioda bosanskohercegovačke historije nakon 1945. godine, tim prije što je politički dirigovani diskurs o Drugom svjetskom ratu nakon

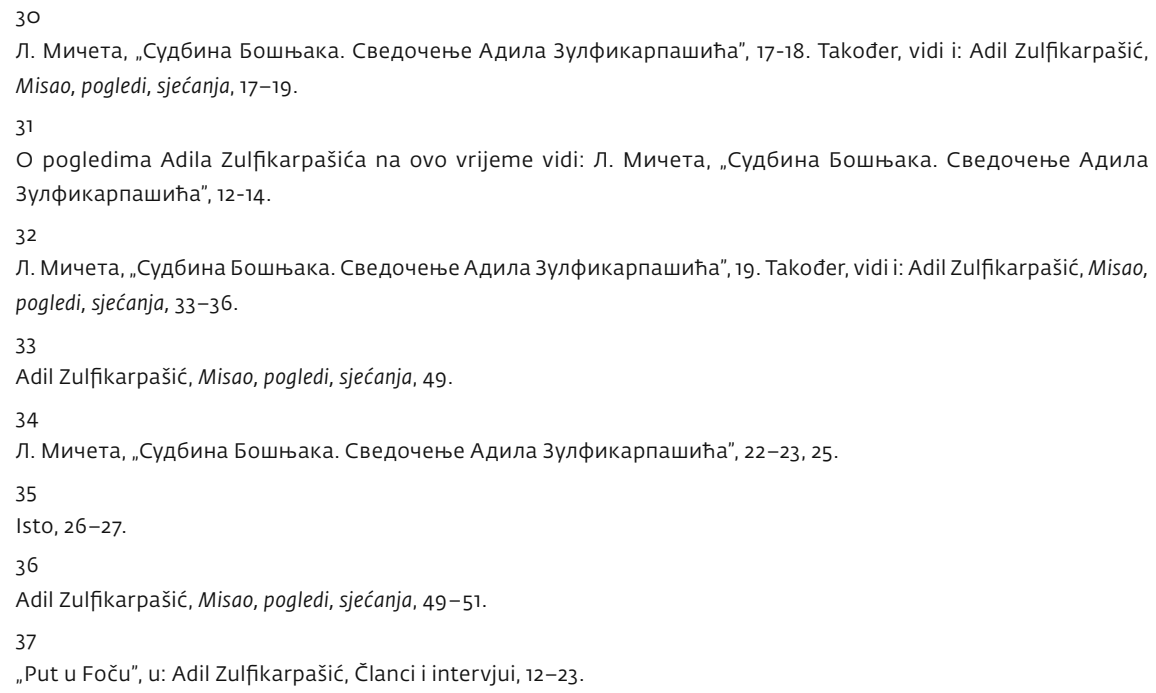


njegova završetka u konačnici rezultirao „osakaćenom historiografijom” ${ }^{38} \mathrm{i}$ nepotpunom slikom Drugog svjetskog rata.

Odlazak u emigraciju je, pored uobičajenih problema koji u vezi s tim mogu biti evidentirani, ${ }^{39} \mathrm{u}$ slučaju Adila Zulfikarpašića kao, kako se to pokazalo nakon kraćeg perioda, najistaknutije ličnosti bošnjačke političke emigracije imao i jednu posebnost u odnosu na druge emigrantske krugove. Srpska i hrvatska emigracija su do sredine 20. stoljeća već bili formirani i prepoznatljivi entiteti izvan jugoslavenskih granica. ${ }^{40} \mathrm{Za}$ razliku od njih, malobrojnija, a politički i nacionalno sigurno dezorijentiranija bila je bošnjačka emigracija, koja se u takvim uvjetima sve do izrastanja Bosanskih pogleda Adila Zulfikarpašića u šezdesetim godinama uvijek nalazila u svojevrsnom procjepu između dviju velikih emigrantskih zajednica, ${ }^{41}$ dijelom i međusobno suprotstavljenih, tražeći mogućnost vlastitog iskaza. To traganje za vlastitim iskazom, a time i mogućnošću za autorefleksijom o sebi, svojoj prošlosti, sadašnjosti i budućnosti, neminovno je nosilo osjećaj potrebe za saradnjom sa drugim emigrantskim zajednicama „umjerenog političko-nacionalnog držanja” i suprotstavljanje onima koje to nisu bile, poput radikalnih nacionalističkih emigrantskih skupina, dok je, prema Zulfikarpašićevom svjedočenju, postojao „ozbiljan kontakt” demokratski orijentirane srpske, hrvatske i bošnjačke emigracije, jer se „to gajilo, stvarala su se, dapače, i prijateljstva”. ${ }^{42}$

U takvom kontekstu treba razumijevati izrastanje i međusobno umrežavanje bošnjačke inteligencije u emigraciji te njihovu prepoznatljivost i definiranje kako identitetskih tako i političkih pozicija kroz Bosanske poglede, „, čemu je uloga Adila Zulfikarpašića određujuća”, kako je to zabilježio Šaćir Filandra u svojoj knjizi o bošnjačkoj politici u 2o. stoljeću. ${ }^{43}$ Tako su u šezdesetim godinama Bosanski pogledi postali autentični izraz političko-ideološkog opredjeljenja iza kojeg je stajao Adil Zulfikarpašić, u međuvremenu izgrađena i prepoznatljiva ličnost liberalno-demokratskih političkih uvjerenja i autentični iskaz evropskog muslimanskog identiteta. Tokom šezdesetih godina snažno

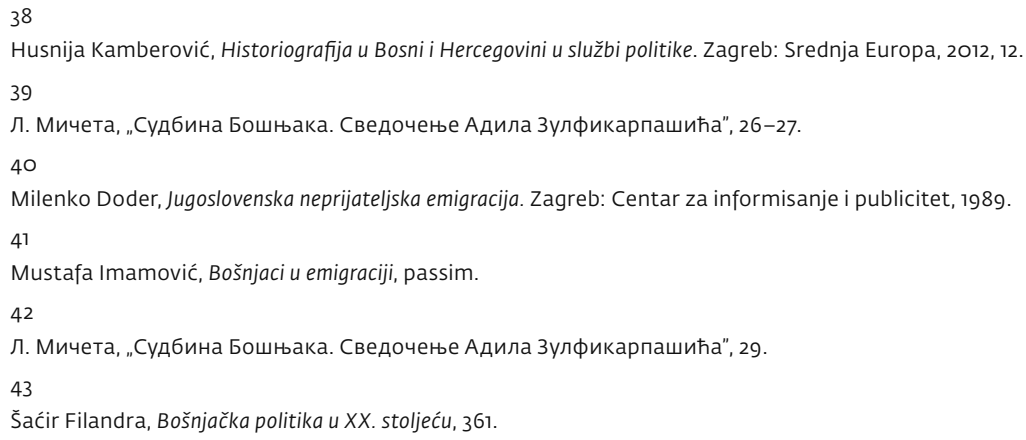


se aktivirao u Liberalnoj svjetskoj internacionali, a sigurno je njegovom takvom pozicioniranju znatno pomogla i činjenica da je u drugoj polovini 20. stoljeća postao i uspješan biznismen, ${ }^{44}$ koji je, učestvujući i posredujući u poslovima na svjetskom nivou, izgradio imidž povjerljive i pouzdane osobe. ${ }^{45}$ Bez takvih bi kvaliteta mnogo drugoga bilo teže ostvarivo, a pouzdano bi se moglo kazati i da tok Zulfikarpašićeve lične historije na kraju 20. stoljeća ne bi bio onakav kakav nam je danas poznat. To se prije svega odnosi na opredjeljenje za osnivanje i početak rada Bošnjačkog instituta u Zürichu, ${ }^{46}$ ali i Zulfikarpašićev politički angažman u procesu demokratizacije jugoslavensko-bosanskohercegovačke i bošnjačke političke scene devedesetih godina. ${ }^{47}$ Iako je njegov angažman na pluralizaciji političke scene u Bosni i Hercegovini prepoznata politička aktivnost, od učešća u osnivanju i radu Stranke demokratske akcije, ${ }^{48}$ a zatim i kroz Muslimansko-bošnjačku organizaciju, ${ }^{49}$ ipak je potrebno skrenuti pažnju na činjenicu da bošnjačka politička emigracija „,nije bila takvog obima i takve snage da bi u urušavanju komunizma preuzela ulogu predvoditeljskog ili oblikujućeg činioca nacije”. ${ }^{50}$

Iako je Zulfikarpašić svoj „dugoočekivani povratak” u Bosnu i Hercegovinu započeo s pozicija političkog djelovanja kroz podršku formiranju i početak rada Stranke demokratske akcije, ${ }^{51}$ a kasnije i vlastiti politički projekat Muslimansko-bošnjačku organizaciju, ${ }^{52}$ posljednju deceniju 20. stoljeća i početak novog milenija u Zulfikarpašićevoj biografiji ipak treba pamtiti kroz njegov najveći uspjeh i najznačajniji doprinos bosanskohercegovačkoj i bošnjačkoj, ali i općoj kulturi. Naime, sada već u ozbiljnim godinama i

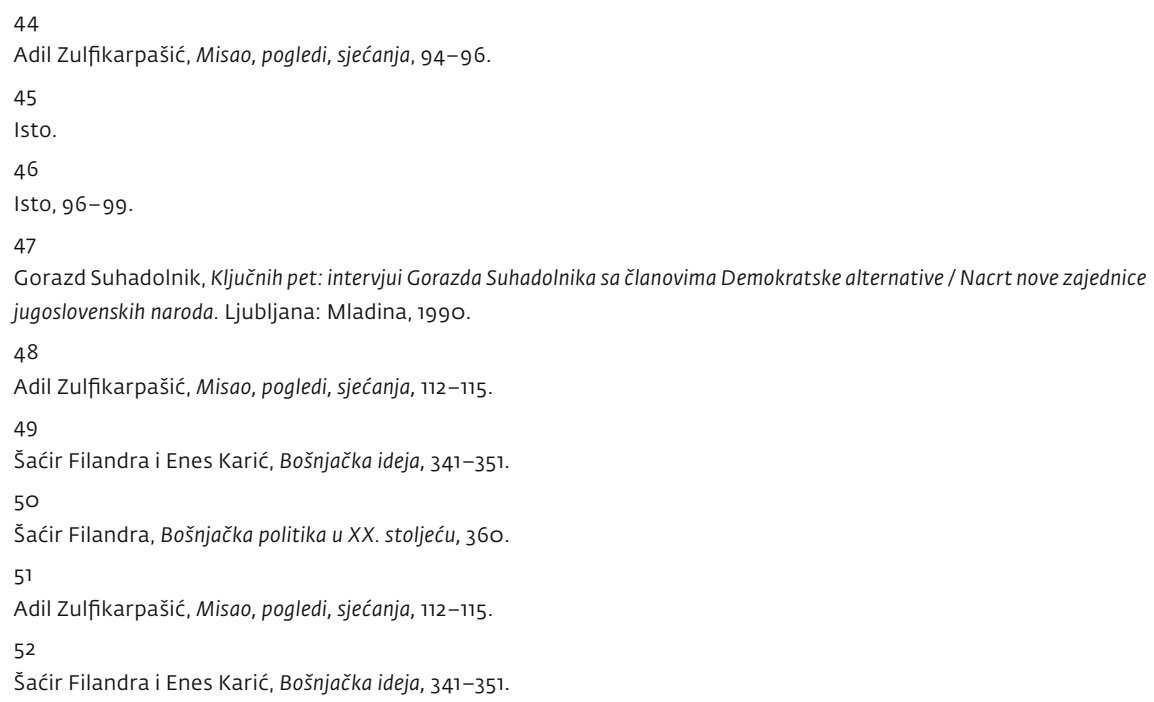


poodmakloj dobi, Zulfikarpašić se radom počeo vraćati svojim korijenima. ${ }^{53}$ Ovo, dakako, ne treba razumijevati samo i isključivo kao povratak u Bosnu i Hercegovinu nego i kao osvjedočenje trajnog opredjeljenja prema njoj. Naime, opredjeljenje da se s kraja osamdesetih godina formirani Bošnjački institut iz Züricha premjesti u Sarajevo u svakom slučaju treba razumjeti kao najznačajniji, pa i politički, potez Adila Zulfikarpašića. Nastojanje da se ulaganjem u agresijom na Bosnu i Hercegovinu devastirano i uništeno Sarajevo obnovi ne samo određeni objekat u kojem bi bile smještene i po volji dobrotvora javnosti dostupne brojne i izuzetno vrijedne zbirke i fondovi rukopisne i bibliotečke građe, umjetnina i drugih vrijednosti značajno je i po tome što se Zulfikarpašićevom fondacijom počela iznova vraćati ideja i duh velikih individualnih vakufa, toliko prepoznatljiva i značajna institucija političke i kulturne historije kako Bošnjaka tako i Bosne i Hercegovine u cjelini. ${ }^{54} \mathrm{U}$ tom smislu je njegova lična volja, individualni čin zavještanja imovine instituciji koju je formirao i u prethodnim decenijama mukotrpno gradio u određenom smislu vraćanje korijenima, odnosno ideji da velike ličnosti bosanskohercegovačke i bošnjačke historije „svoje mjesto u historiji” osiguravaju ,velikim djelom”. Zulfikarpašićevo opredjeljenje je tim značajnije jer na konkretnom primjeru pokazuje da tradicija vakufa u Bosni i Hercegovini nije samo pitanje njene prošlosti nego i sadašnjosti, ali da može i treba biti dio i zalog njene budućnosti. Bošnjački institut je, sa svim onim što predstavlja kao ideja i kao realizacija, prema navedenom, najznačajniji segment kulturnog naslijeđa Adila Zulfikarpašića u Bosni i Hercegovini, tim više jer se njegov politički projekat, stranka, nije razvijao u pravcu koji bi rezultirao značajnijim političkim uspjehom ili participiranjem u vlasti u odlučujućim omjerima. Kada se devedesetih godina 2o. stoljeća u jednom razgovoru za medije izjašnjavao o tome kako vidi budućnost Bosne i Hercegovine, Zulfikarpašić je naglašavao kako će Bosna i Hercegovina i Bošnjaci u Evropu ući, između ostalog, „uz jednu jaku, modernu političku organizaciju kakva je $\mathrm{MBO}$..${ }^{55}$ Deceniju kasnije, na pragu novog milenija, Muslimanska bošnjačka organizacija praktično nije postojala, ali je u posebno organiziranoj svečanosti u Sarajevu otvoren Bošnjački institut - Fondacija Adila Zulfikarpašića, čime je „ostvaren san generacija bošnjačkih intelektualaca” jer se, uz već ranije spomenute fondove i zbirke rukopisne i arhivske građe, „posredstvom zdanja hamama

53

Л. Мичета, „Судбина Бошњака. Сведочење Адила зулфикарпашића”, 34-35. Vidi i: Šaćir Filandra i Enes Karić, Bošnjačka ideja, 315-339.

54

Šaćir Filandra i Enes Karić, Bošnjačka ideja, 315

55

VOX, br. 7, 1990, 34 
(izgrađen 1555. godine) ostvario [se] historijski susret dva vakufa. Jedan Gazi Husrev-begov, nastao u vrijeme kada su islamska kultura, obrazovanje i učenost doživljavali svoj osvit u Bosni i Hercegovini, i drugi vakuf, Adil-begov, koji će Bošnjacima pomoći da očuvaju svoju samobitnost kako danas tako i u budućnosti”. ${ }^{56}$

\section{Bibliografija}

\section{ŠTAMPA}

1. НИН

2. Oslobođenje

3. Valter Express

4. Vox

\section{ČLANCI I KNJIGE}

1. Asboth, Johann, Bosnien und die Herzegowina. Reisebilder und Studien. Wien: 1888. (dio prijevoda pod naslovom „Foča i Zagorje” objavljen u časopisu Život, br. 1, 1979, 74-93)

2. Bandžović, Safet, Iseljavanje Bošnjaka u Tursku. Sarajevo: Institut za istraživanje zločina protiv čovječnosti i međunarodnog prava Univerziteta u Sarajevu, 2006.

3. Čalić, Mari-Žanin, Jugoistočna Evropa: globalna historija. Sarajevo: Udruženje za modernu historiju, 2020.

4. Duranović, Amir, „Debate About Personality as a Factor in Modern Bosnian History: An Assesment of Historiography of Bosnia and Herzegovina”, Historia Moderna - Bosnia \& Herzegovina, god. I, br. 1, 2020, 43-56.

5. Fahrudin Đapo i Tihomir Loza, Povratak u Bosnu (razgovori s Adilom Zulfikarpašićem). Ljubljana: Karantanija, 1990.

6. Filandra, Šaćir i Karić, Enes, Bošnjačka ideja. Zagreb: Nakladni zavod Globus, 2002.

7. Filandra, Šaćir, Bošnjačka politika u XX. stoljeću. Sarajevo: Sejtarija, 1998.

8. Imamović, Mustafa, Bošnjaci u emigraciji: monografija „Bosanskih pogleda”. Zürich (odjel Sarajevo): Bošnjački institut, 1996.

9. Kamberović, Husnija, Begovski zemljišni posjedi u Bosni i Hercegovini od 1878. do 1918. godine. Sarajevo: Naučnoistraživački institut „Ibn Sina”, drugo izdanje, 2005.

10. Kamberović, Husnija, Džemal Bijedić: politička biografija, 2. dopunjeno izdanje. 
Sarajevo: Udruženje za modernu historiju / Udruga za modernu povijest Sarajevo, Edicija: Studije za historiju BiH, knj. 3, 2017.

11. Kamberović, Husnija, Džemal Bijedić: politička biografija. Mostar: Muzej Hercegovine, 2012.

12. Kamberović, Husnija, Historiografija u Bosni i Hercegovini u službi politike. Zagreb: Srednja Europa, 2012.

13. Kamberović, Husnija, Mehmed Spaho (1883-1939): politička biografija. Sarajevo: Vijeće Kongresa bošnjačkih intelektualaca, 2009.

14. Kreševljaković, Hamdija, Čengići: prilog proučavanju feudalizma u Bosni i Hercegovini. Sarajevo, 1959.

15. Milovan Đilas i Nadežda Gaće, Bošnjak Adil Zulfıkarpašić. Zürich: Bošnjački institut, 1994.

16. Mulaosmanović, Admir, Iskušenje opstanka: Izetbegovićevih deset godina 1990.-2000. Sarajevo: Dobra knjiga, 2013.

17. Mulaosmanović, Admir, Iskušenje opstanka. Izetbegovićevih deset godina 1990.-2000. 2. izdanje. Sarajevo, 2017.

18. Mutapčić, Edin, Agrarna reforma u BiH i njeno zakonodavstvo (1918.-1941.). Gradačac: Javna biblioteka „Alija Isaković”, 2007.

19. Narodne pjesme Bošnjaka u Bosni i Hercegovini, I-II, Sabrao Kosta Hörmann 1888-1889. Sarajevo, 1996.

20. Pezo, Edvin, Zwangsmigration in Friedenszeiten? Jugoslawische Migrationspolitik und die Auswanderung von Muslimen in die Türkei (1918 bi 1966), Südosteuropäische Arbeiten, 146, Oldenbourg Verlag, 2013.

21. Sarač-Rujanac, Dženita, Branko Mikulić: politička biografija: 1965-1989. Sarajevo: Institut za historiju Univerziteta u Sarajevu, 2020.

22. Suhadolnik, Gorazd, Klučnih pet: intervjui Gorazda Suhadolnika sa članovima Demokratske alternative/Nacrt nove zajednice jugoslovenskih naroda. Ljubljana: Mladina, 1990.

23. Zlatar, Behija, Gazi Husrev-beg. Sarajevo: Orijentalni institut, 2010.

24. Zulfikarpašić, Adil, Članci i intervjui (prir. Nadežda Gaće). Zürich (i odjel Bošnjačkog instituta u Sarajevu): Bošnjački institut, 1991.

25. Zulfikarpašić, Adil, Misao, pogledi, sjećanja. Sarajevo: Bošnjački institut - Fondacija Adila Zulfikarpašića, 2005. 


\section{Political and Cultural Heritage of Adil Zulfikarpašić}

ABSTRACT: In this paper, the author gives a draft for a study on the political and cultural heritage of Adil Zulfikarpašić, his origin, attitude towards politics, emigration, political engagement and the most important endowment of the contemporary Bosniak cultural scene - the Bosniak
Institute - Adil Zulfikarpašić Foundation, which was founded in Switzerland and now operates in Bosnia and Herzegovina.

KEYWORDS: Adil Zulfikarpašić, Bosnia @ Herzegovina, Bosniaks, Bosniak Institute. 